\title{
Oxidative Cleavage-Based Three-Dimensional DNA Biosensor for Ratiometric Detection of Hypochlorous Acid and Myeloperoxidase
}

Jing Wang ${ }^{\mathrm{a}}$, Jia-Yi Ma ${ }^{\mathrm{a}}$, Dong-Xia Wang ${ }^{\mathrm{a}}$, Bo Liu ${ }^{\mathrm{a}}$, Xiao Jing ${ }^{\mathrm{a}}$, Dan-Ye Chen ${ }^{\mathrm{a}}$, An-Na Tang ${ }^{\mathrm{a}}$, and De-Ming Konga*

${ }^{a}$ State Key Laboratory of Medicinal Chemical Biology, Tianjin Key Laboratory of Biosensing and Molecular Recognition, Research Centre for Analytical Sciences, College of Chemistry, Nankai University, Tianjin, 300071, P R China

*E-mail: kongdem@nankai.edu.cn 


\section{Table of Content}

Experimental Section

Materials and instruments

Assembly and characterization of probes

HOCl-triggered cleavage reaction

HOCl-triggered DNA assembly

$\mathrm{HOCl}$ sensitivity and kinetics

Specificity experiments for $\mathrm{HOCl}$ detection

MPO activity measurement

Detection of MPO activity in real samples

Detection of MPO activity by a portable device

Additional Figures and Tables

S8 


\section{Experimental Section}

\section{Materials and instruments}

Myeloperoxidase (MPO) from human leukocytes, 4-aminobenzoic acid hydrazide (4-ABAH), 3\% hydrogen peroxide $\left(\mathrm{H}_{2} \mathrm{O}_{2}\right)$ aqueous solutions, lipopolysaccharide (LPS) and sodium hypochlorite $(\mathrm{NaOCl})$ were purchased from Sigma Aldrich (Shanghai, China). Hypoxanthine, xanthine oxidase, catalase, tert-butyl hydroperoxide (TBHP), BSA, HRP, NADPH, glucose oxidase, and glucose reductase were purchased from Solarbio Science \& Technology (Beijing, China). SYBR Gold Nucleic Acid Gel Stain was obtained from Thermo Fisher Scientific. All solutions for the reaction were prepared with ultrapure water which was purified by a Milli-Q water purification system $(>18.25 \mathrm{M} \Omega / \mathrm{cm})$. Oligonucleotides were synthesized by Sangon Biotech (Shanghai, China) and purified by high-performance liquid chromatography prior to use. These DNA sequences are listed in Table S1. Myeloperoxidase (MPO) test kit was purchased from Shanghai Beibo Biotechnology Co., Ltd. Fluorescence spectra was measured by Hitachi RF-5301 fluorescence spectrometer (Hitachi. Ltd., Japan). Gel electrophoresis result was obtained by a Gel Documentation System (Huifuxingye, Beijing, China). 96-well plates were measured in the BioTek Synergy 4 microplate reader (BioTek Instruments Inc., USA).

Table S1. List of oligonucleotides used in this work.

\begin{tabular}{ll}
\hline Name & Sequence (left to right: $5^{\prime}$ to $\left.3^{\prime}\right)^{[\text {a] }}$ \\
\hline S1 & CCAAAAAAAAAAAAAAAAAAAAAACATTCCTAAGTCTGAAACATTACAGCTT \\
& GCTACACGAGAAGAGCCGCCATAGTA \\
S2 & CCAAAAAAAAAAAAAAAAAAAAAATATCACCAGGCAGTTGACAGTGTAGCAAG \\
& CTGTAATAGATGCGAGGGTCCAATAC \\
S3 & CCAAAAAAAAAAAAAAAAAAAAAATCAACTGCCTGGTGATAAAACGACACTAC \\
& GTGGGAATCTACTATGGCGGCTCTTC \\
S4 & CCAAAAAAAAAAAAAAAAAAAAAATTCAGACTTAGGAATGTGCTTCCCACGTA \\
In & GTGTCGTTTGTATTGGACCCTCGCAT \\
Lock0 & TAGCATATCACACTGATGTTGA \\
Lock1 & AACATCAGTGTGATATGC \\
Lock2 & AACATCAGT*GTG*ATATGC \\
Lock3 & AACATC*AGT*GTG*ATATGC
\end{tabular}




\begin{tabular}{|c|c|}
\hline Lock4 & TCAACAT*CAGTGTGA*TATGCTA \\
\hline Lock5 & TCAACATCAGT*G*TGATATGCTA \\
\hline Lock6 & TCAACATCAG*T*G*TGATATGCTA \\
\hline Lockin & TAGCATATCACACTGATGTTGATTTTTTAACATCAGT*GTGATATGC \\
\hline Lock $^{\mathrm{FAM}}$ & FAM-AACATCAGT*GTGATATGC \\
\hline $\begin{array}{l}\text { Cleavage } \\
\text { fragment1 }\end{array}$ & FAM-AACATCAGT \\
\hline h1 & TCAACATCAGTGTGATATGCTACTAAGTTAGCATATCACACTG \\
\hline h2 & TAGCATATCACACTGATGTTGACAGTGTGATATGCTAACTTAG \\
\hline H1 & $\begin{array}{l}\text { TTTTTTTTTTTTTTTTTTTTTTGGTCAACATCAGTGTGATATGCTACTAAGTTAGCA } \\
\underline{\text { TATCACACTG }}\end{array}$ \\
\hline $\mathrm{H} 2$ & $\begin{array}{l}\text { TTTTTTTTTTTTTTTTTTTTTTGGTAGCATATCACACTGATGTTGACAGTGTGATAT } \\
\text { GCTAACTTAG }\end{array}$ \\
\hline $\mathrm{H} 11^{\mathrm{Cy} 3}$ & $\begin{array}{l}\text { TTTTTTTTTTTTTTTTTTTTTTGGTCAACATCAGTGTGATATGCTAC/iCy3dT/AAGT } \\
\underline{\text { TAGCATATCACACTG }}\end{array}$ \\
\hline $\mathrm{H} 2^{\mathrm{Cy} 5}$ & $\begin{array}{l}\text { TTTTTTTTTTTTTTTTTTTTTTGGTAGCATATCACACTGATGTTGACAGTGTGATAT } \\
\text { GCTAACTTAG-Cy5 }\end{array}$ \\
\hline $\mathrm{H} 1^{\mathrm{FQ}}$ & $\begin{array}{l}\text { TTTTTTTTTTTTTTTTTTTTTTGGTCAACA/i6AlexaFluor488dT/CAGTGTGATATGCT } \\
\text { ACTAAGTTAGCATATCACACTG-BHQ1 }\end{array}$ \\
\hline
\end{tabular}

[a] The code names for fluorophore and quencher modifications are according to Sangon Biotech. Modified nucleotides, $\mathbf{T}^{*}$ and $\mathbf{G}^{*}$ : phosphorothioate (PS) versions of T and G. The underlined sequences are complementary.

\section{Assembly and characterization of probes}

To construct P1, $1 \mu \mathrm{M}$ of Strands S1, S2, S3, S4 and $4 \mu \mathrm{M}$ H1 were mixed in TM buffer (20 mM Tris$\mathrm{HCl}, 50 \mathrm{mM} \mathrm{MgCl} 2, \mathrm{pH}=8.0$ ). Annealing was performed by heating to $95{ }^{\circ} \mathrm{C}$ for $5 \mathrm{~min}$, then cooling to $4{ }^{\circ} \mathrm{C}$ within $1 \mathrm{~min}$. The obtained probes were then directly used for characterization without further fractionation or purification. The synthesis of $\mathbf{P 2}$ requires only the replacement of $\mathbf{H 1}$ with $\mathbf{H 2}$, and the other steps are similar to those described above.

To construct Lock-In, PS-modified Lock and In were mixed in equimolar ratios to a final concentration of $10 \mu \mathrm{M}$ in $10 \mathrm{mM}$ phosphate buffer saline, $\mathrm{pH}$ 7.4. Annealing was performed by heating to $95^{\circ} \mathrm{C}$ for $5 \mathrm{~min}$, cooling to room temperature over $2 \mathrm{~h}$ and equilibrating at $25^{\circ} \mathrm{C}$. 
Formation of probes was confirmed by a gel mobility shift assay using 10\% native PAGE. For PAGE experiment, samples after reaction were each mixed with an equivalent volume of a loading buffer containing $0.03 \%$ bromophenol blue and $0.03 \%$ xylene cyanol FF, and were electrophoresed at $120 \mathrm{~V}$ for about $50 \mathrm{~min}$ on $10 \%$ native polyacrylamide gels in $1 \times$ TBE buffer (Tris-borate-EDTA, $\mathrm{pH} 7.4$, from Thermo Fisher Scientific). The gels were stained with GelRed (Takara) in advance and visualized with a Gel Image System.

\section{HOCl-triggered cleavage reaction}

A solution of $2 \mu \mathrm{M}$ PS-modified Lock or Lock-In in $10 \mathrm{mM}$ PBS (pH 7.4) was added with different amount of $\mathrm{HOCl}$. The solution was then kept for $1 \mathrm{~h}$ at $37^{\circ} \mathrm{C}$ to complete cleavage of PS linkages by $\mathrm{HOCl}$. After GelRed staining, the gels were visualized with a Gel Image System.

\section{HOCl-triggered DNA assembly}

Probes (P1, P2 and Lock-In) were mixed with different concentrations of HOCl. The mixture was then isothermally incubated at $37^{\circ} \mathrm{C}$ for proper time. Agarose gel electrophoresis was applied to characterize the successful preparation of DNA assemblies. The reaction solutions were separated by $2 \%$ agarose gel electrophoresis at room temperature $(80 \mathrm{~V}, 20 \mathrm{~min})$. The gels were stained with GelRed in advance and visualized with a Gel Image System.

\section{HOCI sensitivity and kinetics}

Solutions of $50 \mathrm{nM}$ P1, $50 \mathrm{nM}$ P2 and $500 \mathrm{nM}$ Lock-In in $100 \mu \mathrm{L}$ PBS buffer ( $\mathrm{pH}=7.4$ ) were incubated with $\mathrm{HOCl}(0$ to $10 \mu \mathrm{M})$ for $30 \mathrm{~min}$ at $37^{\circ} \mathrm{C}$. Then, the fluorescence spectrum of the mixture was collected from 550 to $800 \mathrm{~nm}$ with $548 \mathrm{~nm}$ excitation. $\mathrm{F}_{\mathrm{A}}$ and $\mathrm{F}_{\mathrm{D}}$ are the fluorescence of Cy5 at $665 \mathrm{~nm}$ and Cy3 at 561 $\mathrm{nm}$, respectively. Blank control was corrected and normalized to no added $\mathrm{HOCl}$. All experiments were repeated at least three times.

For kinetic studies, 50 nM P1, 50 nM P2 and 500 nM Lock-In were added to a cuvette at pH 7.4 and 37 ${ }^{\circ} \mathrm{C}$ and initial fluorescence intensity at $561 \mathrm{~nm}$ and $665 \mathrm{~nm}$ were measured. To this, $0.1 \mu \mathrm{M}$ and $1 \mu \mathrm{M} \mathrm{HOCl}$ was added, and the spectra were taken at $561 \mathrm{~nm}$ and $665 \mathrm{~nm}$ channels every $1 \mathrm{~min}$. The ratio of $\mathrm{F}_{\mathrm{A}} / \mathrm{F}_{\mathrm{D}}$ at each time point was plotted against incubation time.

\section{Specificity experiments for HOCl detection}

Aqueous $\mathrm{NaOCl}$ served as a $\mathrm{HOCl}$ donor, whereby $\mathrm{OCl}^{-}$concentration was quantified using $\varepsilon=350 \mathrm{M}^{-1}$ 
$\mathrm{cm}^{-1}$ at $292 \mathrm{~nm}$. For interference experiment of other ROSs, aqueous $\mathrm{H}_{2} \mathrm{O}_{2}$ served as a $\mathrm{H}_{2} \mathrm{O}_{2}$ donor, whereby its concentration was quantified using $\varepsilon=43.6 \mathrm{M}^{-1} \mathrm{~cm}^{-1}$ at $240 \mathrm{~nm}$. Xanthine/xanthine oxidase was used to generate superoxide $\left(\mathrm{O}_{2}{ }^{-}\right)$. The rate of $\mathrm{O}_{2}^{-}$synthesis (about $3.1 \mu \mathrm{M} / \mathrm{min}$ ) was quantified using cytochrome c reduction as described ${ }^{1} \cdot \cdot \mathrm{OH}$ was produced by adding $\mathrm{Fe}^{2+}$ to the solution containing excess $\mathrm{H}_{2} \mathrm{O}_{2}$. TBHP stock solution (10 mM) was obtained by adding $1.2 \mu \mathrm{L}$ of $70 \%$ (wt/vol) TBHP to $998.8 \mu \mathrm{L}$ of $\mathrm{H}_{2} \mathrm{O}$. NO stock solution $(10 \mathrm{mM})$ was obtained by dissolving $2.98 \mathrm{mg}$ of sodium nitroprusside dihydrate in $1 \mathrm{~mL}$ of $\mathrm{H}_{2} \mathrm{O}$.

ROS/RNS generators were added to probes (50 nM P1, 50 nM P2 and 500 nM Lock-In) in $100 \mu \mathrm{L}$ PBS buffer $(\mathrm{pH}=7.4)$ to a final concentration of $10 \mu \mathrm{M}$ reactive species, except for $\mathrm{HOCl}$, in which $1 \mu \mathrm{M} \mathrm{HOCl}$ was added. Samples were incubated for $30 \mathrm{~min}$ at $37^{\circ} \mathrm{C}$, and fluorescence spectra were recorded in all channels.

\section{MPO activity measurement}

MPO solution was prepared by dissolving MPO in $1 \mathrm{~mL}$ of water (containing $20 \%$ of glycerol). The solution was stored at $4{ }^{\circ} \mathrm{C}$ and used within 2 weeks. Solutions of $50 \mathrm{nM}$ P1, $50 \mathrm{nM}$ P2 and $200 \mathrm{nM}$ Lock-In in $100 \mu \mathrm{L} \mathrm{PB}$ buffer $(\mathrm{pH}=6.0)$ were incubated with MPO $(0$ to $1 \mu \mathrm{g} / \mathrm{mL})$ for $30 \mathrm{~min}$ at $37{ }^{\circ} \mathrm{C}$. Then, the fluorescence spectrum of the mixture was collected from 550 to $800 \mathrm{~nm}$ with $548 \mathrm{~nm}$ excitation. $\mathrm{F}_{\mathrm{A}}$ and $\mathrm{F}_{\mathrm{D}}$ are the fluorescence of $\mathrm{Cy} 5$ at $665 \mathrm{~nm}$ and $\mathrm{Cy} 3$ at $561 \mathrm{~nm}$, respectively. Blank control was corrected and normalized to no added MPO. All experiments were repeated at least three times.

For kinetic studies, $50 \mathrm{nM}$ P1, $50 \mathrm{nM}$ P2 and $200 \mathrm{nM}$ Lock-In were added to a cuvette and initial fluorescence intensity at $561 \mathrm{~nm}$ and $665 \mathrm{~nm}$ was measured. To this, 0, 5, 50 ng/mL of MPO were added, and spectra were taken at $561 \mathrm{~nm}$ and $665 \mathrm{~nm}$ channels every 1 min. The ratio of $F_{A} / F_{D}$ at each time point was plotted against time.

For exploring effect of the halogen ions on this system, the MPO standards solutions should be centrifuged 3 times with a $10 \mathrm{k}$ ultrafiltration tube (10k, Amicon Ultra- 0.5$)$ to remove chloride before cleavage reaction.

The inhibitor (4-ABAH) of MPO was diluted with DMSO. In this experiment, added 4-ABAH directly into the MPO $(50 \mathrm{ng} / \mathrm{mL})$ solution, and then incubated for $30 \mathrm{~min}$ at $37^{\circ} \mathrm{C}$ before cleavage reaction.

\section{Detection of MPO activity in real samples}

Serum/plasma: We purchased human serum and plasma from commercial sources and used it after diluting 100 times with PBS. Different amounts of MPO were added to the diluted human serum and plasma samples for recovery tests. 
Cell lysate: RAW264.7 cells (mouse monocyte macrophage) were obtained from the Cell Bank of Type Culture Collection of the Chinese Academy of Sciences (Shanghai, China) and cultured in DMEM (GIBCO) medium with 10\% FBS and 1\% penicillin-streptomycin (PS, $10000 \mathrm{IU}$ penicillin and $10000 \mu \mathrm{g} / \mathrm{mL}$ streptomycin). Cells were subcultured every 3 days, and cultures were restarted from frozen stocks after 30 passages. Cell lysate was prepared by mixing cells with mammalian cell lysis buffer (50 mM Tris-HCl, 150 $\mathrm{mM} \mathrm{NaCl}, 0.1 \% \mathrm{SDS}, 0.5 \%$ deoxycholic acid and protease inhibitor), followed by centrifugation to remove nuclear DNA and cell membrane debris. Different amounts of MPO were added to the 100-diluted cell lysate samples for recovery tests.

Saliva: Unstimulated whole human saliva samples were collected early in the morning prior to the consumption of any food/drink. Samples were centrifuged at 10,000g for $30 \mathrm{~min}$ and the clear supernatant was transferred to microcentrifuge tubes and stored in a $-20^{\circ} \mathrm{C}$ refrigerator when not in use ${ }^{2}$. Different amounts of MPO were added to the 100-diluted human saliva samples for recovery tests.

The experiments were divided into three control groups: (1) the original sample, (2) the sample spiked with 2.5, 10 or $20 \mathrm{ng} / \mathrm{mL}$ MPO, and (3) the PBS spiked with 2.5, 10 or $20 \mathrm{ng} / \mathrm{mL}$ MPO. MPO content was calculated based on equation 1. The procedure for the fluorescent measurement was conducted in 96 wells microplates. The precision of the method was estimated by the coefficients of variation $(\mathrm{CV})$ calculated for several determinations made in triplicate.

$$
\text { equat i on } 1: \% \text { recovery }=\frac{I(\text { sample spiked })-I(\text { original sample })}{I(\text { PBS spiked })} \times 100
$$

\section{Detection of MPO activity by a portable device}

Finally, the PCR tubes were placed in a homemade chamber using a UV lamp for excitation and a smartphone for capturing the fluorescence images. For semiquantitative testing, the results could be directly read by the naked eye. All experiments were performed three times to ensure reproducibility. The fluorescence images captured by the smartphone camera were transferred to a computer for further analysis using the image processing software ImageJ. An average green channel value was obtained for each detection zone by selecting the whole area of each zone. The average green channel values of the blank samples were used as background. 


\section{Additional Figures and Tables}

The Tm values of the Lock-In, cleverage fragment1-In and cleverage fragment2-In were first evaluated by software. The Tm value of Lock-In is $59.4{ }^{\circ} \mathrm{C}$, which is stable enough at $37{ }^{\circ} \mathrm{C}$. After being cut by hypochlorous acid, the $\mathrm{Tm}$ values of two parts fragment1/In (AACATCAGT versus TAGCATATCACACTGATGTTGA) and fragment2/In (GTGATATGC versus TAGCATATCACACTGATGTTGA) were $36.2{ }^{\circ} \mathrm{C}$ and $30.9{ }^{\circ} \mathrm{C}$, resulting in releasing In from the complex (Lock/In) at $37^{\circ} \mathrm{C}$.

(a)
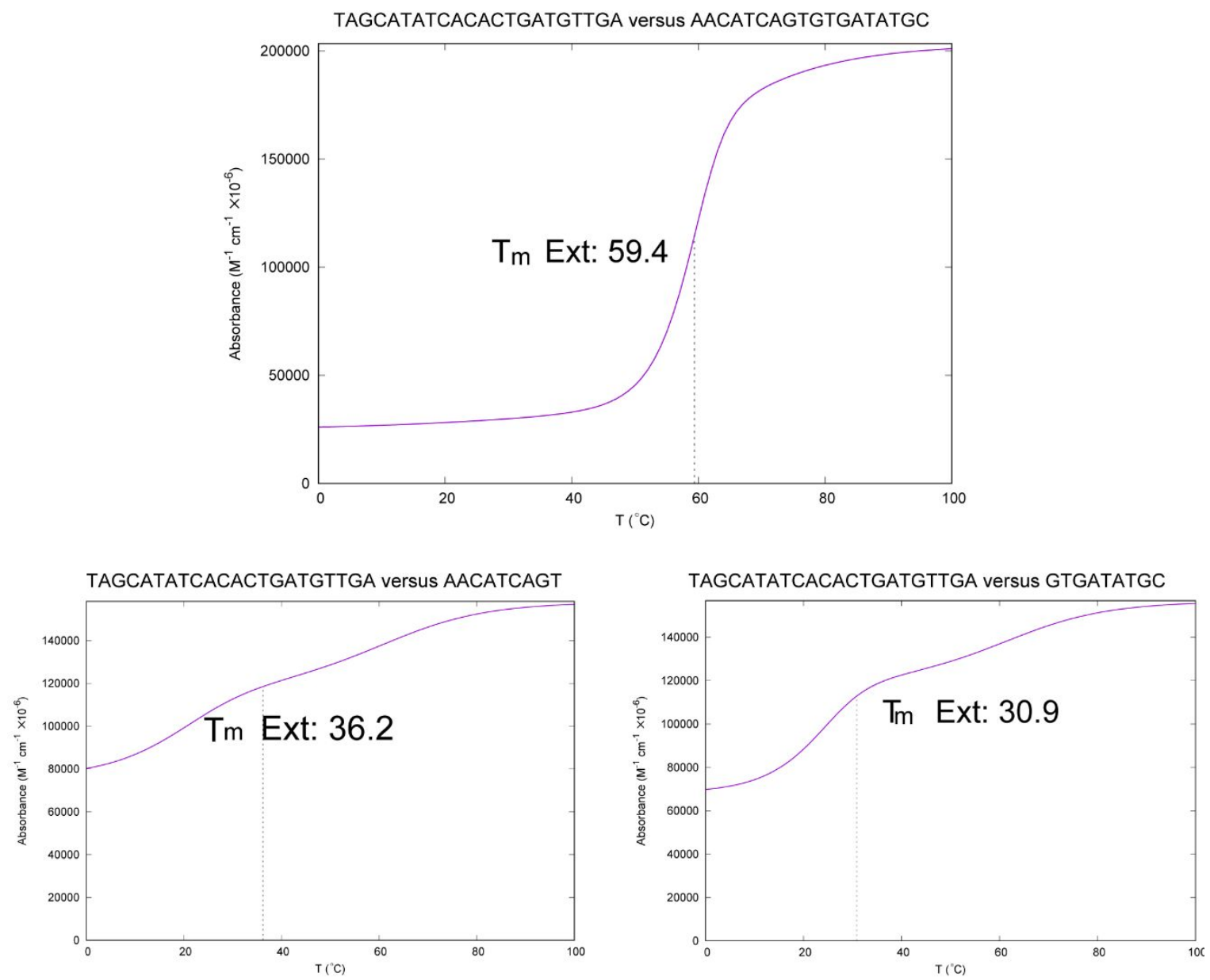

A pair of hairpin probes of $\mathbf{h} \mathbf{1}$ and $\mathbf{h} \mathbf{2}$ were rationally designed for specific In. The ideal secondary structures and corresponding thermodynamic parameters of $\mathbf{h} \mathbf{1}, \mathbf{h} \mathbf{2}, \mathrm{In}, \mathbf{h} \mathbf{1} / \mathrm{In}$ duplex, and $\mathbf{h} \mathbf{1} / \mathbf{h} \mathbf{2}$ duplex were analyzed by the Nupack software under the condition of PBS buffer (pH 7.4) containing $137 \mathrm{mM} \mathrm{NaCl}$ (Figure $\mathrm{S} 1)$. The Gibbs free energy $(\Delta \mathrm{G})$ indicated the thermodynamic feasibility of the HCR process.

(b) 


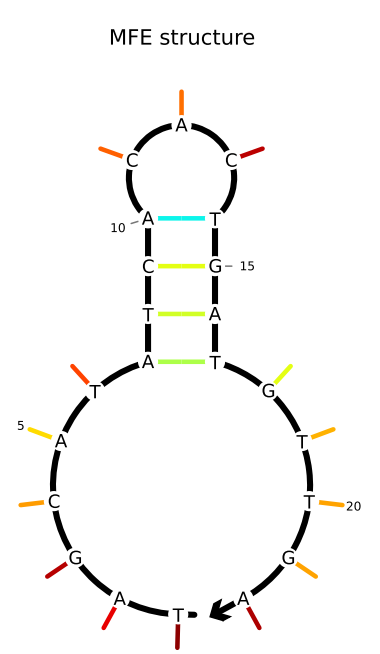

Free energy of secondary structure: $-1.24 \mathrm{kcal} / \mathrm{mol}$

(d)

MFE structure

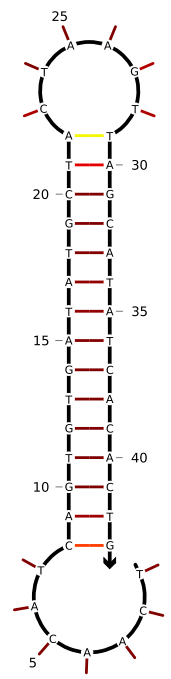

Free energy of secondary structure: $-14.58 \mathrm{kcal} / \mathrm{mo}$

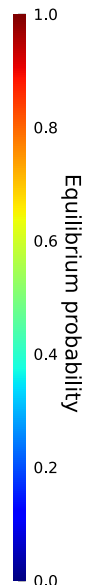

Free energy of secondary structure: $-0.93 \mathrm{kcal} / \mathrm{mol}$

(e)
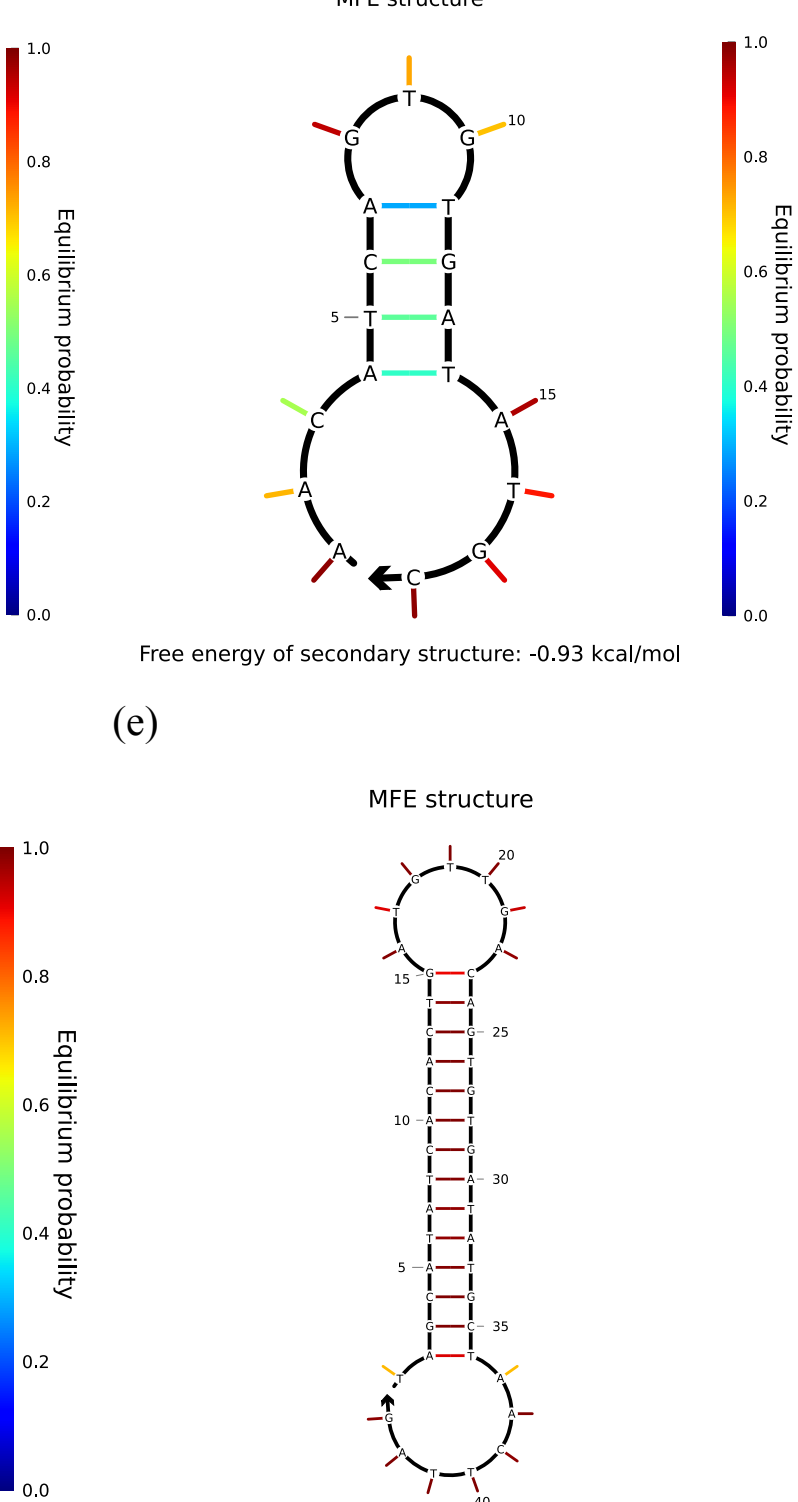

Free energy of secondary structure: $-14.96 \mathrm{kcal} / \mathrm{mol}$

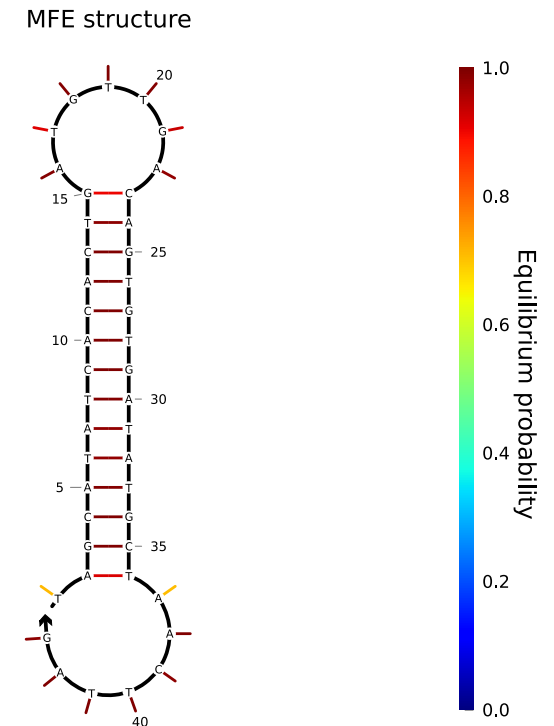


(f)

MFE structure

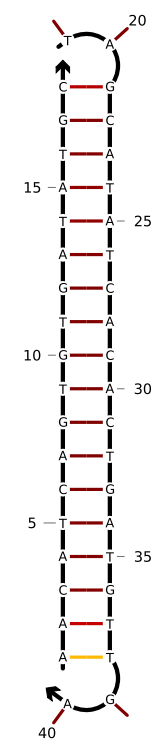

Free energy of secondary structure: $-23.45 \mathrm{kcal} / \mathrm{mol}$ (g)

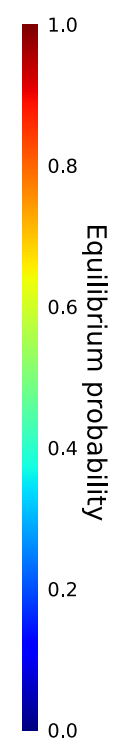

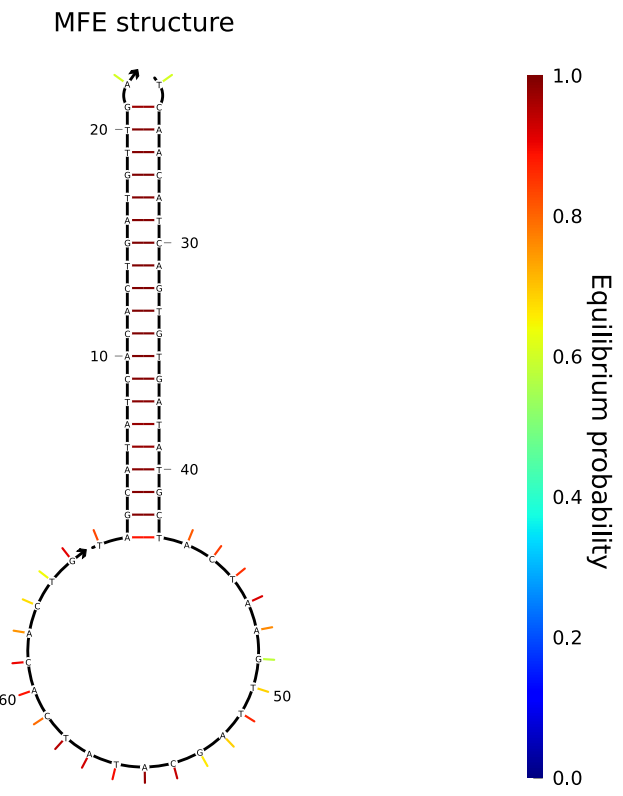

Free energy of secondary structure: $-27.79 \mathrm{kcal} / \mathrm{mol}$

(h)

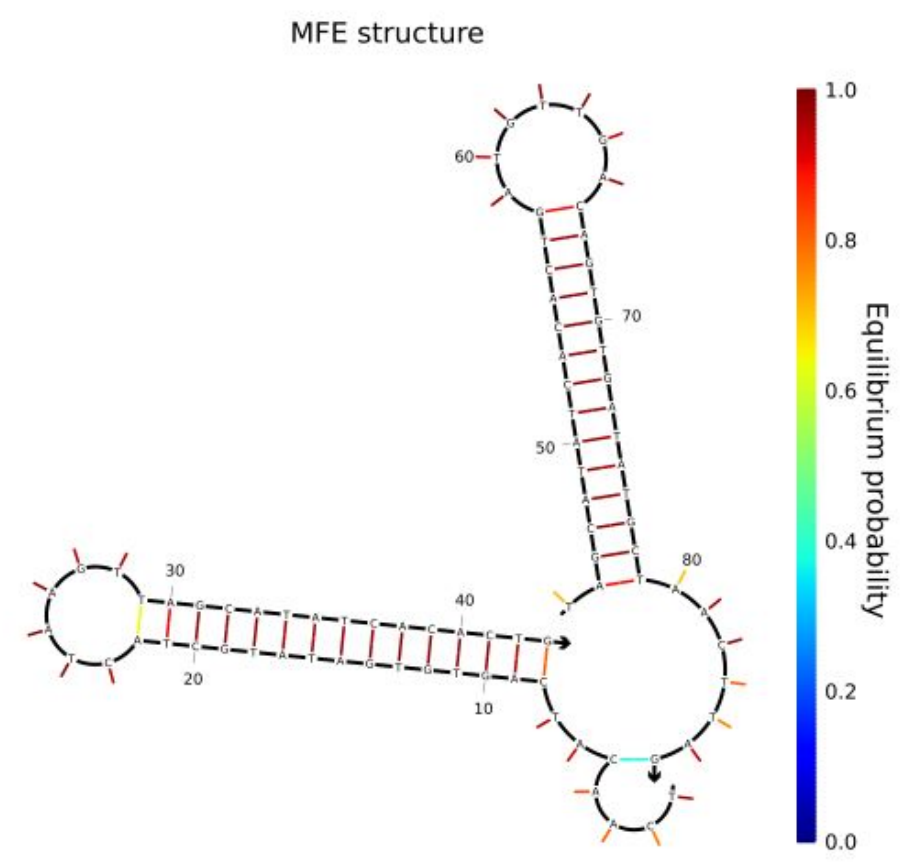

Free energy of secondary structure: $-32.41 \mathrm{kcal} / \mathrm{mol}$

Figure S1. (a) Tm values of the Lock-In, cleverage fragment1-In and cleverage fragment2-In were evaluated by the website (http://www.unafold.org/). Calculated structures and thermal kinetic parameters of (b) In, (c) Lock, (d) h1, (e) h2, (f) Lock/In duplex, (g) In/h1 and (h) h1/h2 duplex. For convenience of calculations, $\mathbf{h} \mathbf{1}$ and $\mathbf{h} \mathbf{2}$ were obtained by removing the $\mathrm{T}_{22} \mathrm{G}_{2}$ tails from $\mathbf{H 1}$ and $\mathbf{H 2} .\left[\mathrm{Na}^{+}\right]=100 \mathrm{mM},\left[\mathrm{Mg}^{2+}\right]=10 \mathrm{mM}, 37^{\circ} \mathrm{C}$. These structures were predicted by NUPACK (http://www.nupack.org/). 


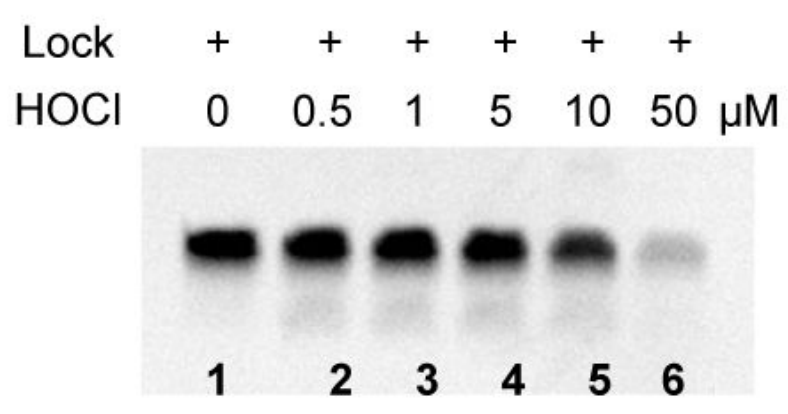

Figure S2. Electrophoretic characterization of $\mathrm{HOCl}$ cleaved PS-modified $\mathbf{L o c k}^{\mathbf{F A M}}$. Condition: $\left[\mathbf{L o c k}^{\mathbf{F A M}}\right]=2 \mu \mathrm{M}, 1 \times \mathrm{PBS}$ buffer, $37^{\circ} \mathrm{C}$ for $1 \mathrm{~h}$, PAGE (10\%).

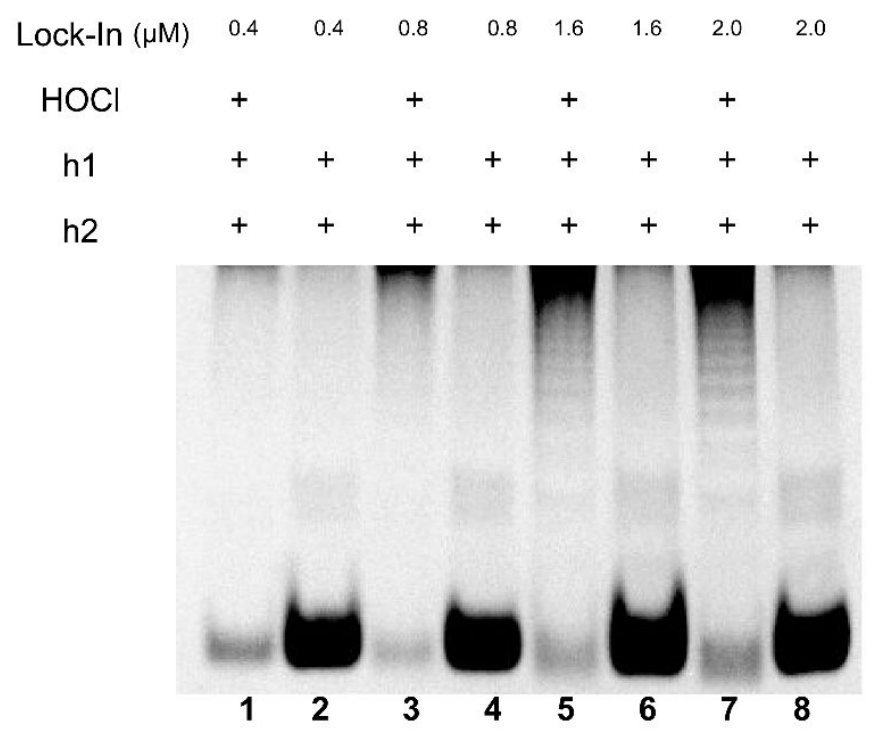

Figure S3. Electrophoretic characterization of the effect of Lock-In concentration on the reaction. Conditions: $[\mathbf{h} 1]=[\mathbf{h} 2]=$ $2 \mu \mathrm{M},[\mathrm{HOCl}]=5 \mu \mathrm{M}, 1 \times \mathrm{PBS}$ buffer, $37^{\circ} \mathrm{C}$ for $4 \mathrm{~h}$, PAGE $(10 \%)$. 
(a)

(b)

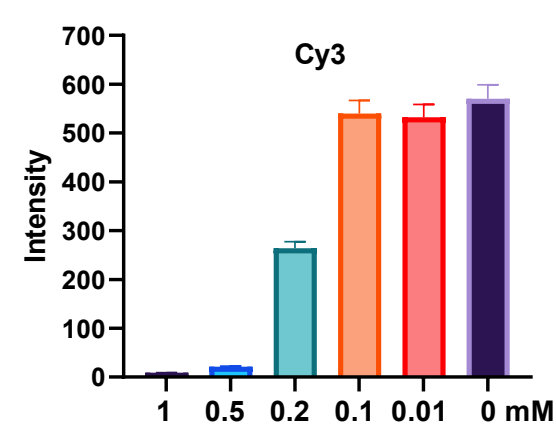

(c)

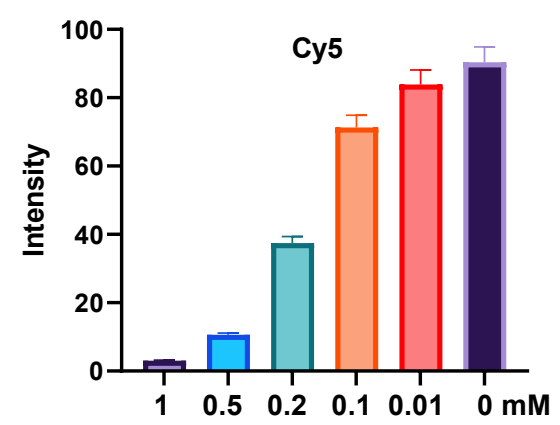

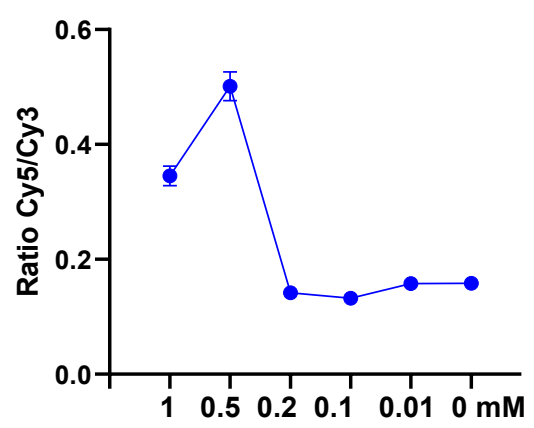

Figure S4. Fluorescence intensity of $200 \mathrm{nM}$ of $\mathbf{H 1}$ (a) or $\mathbf{H 2}$ (b) to $\mathrm{HOCl}(0-1 \mathrm{mM})$. (c) The plot of emission ratio $\left(\mathrm{F}_{665} / \mathrm{F}_{561}\right)$ to $\mathrm{HOCl}(0-1 \mathrm{mM}), \lambda_{\mathrm{ex}}=548 \mathrm{~nm}$. Data were collected at $37^{\circ} \mathrm{C}$ in $1 \times \mathrm{PBS}$ buffer $(\mathrm{pH}=7.4)$ within $60 \mathrm{~s}$.

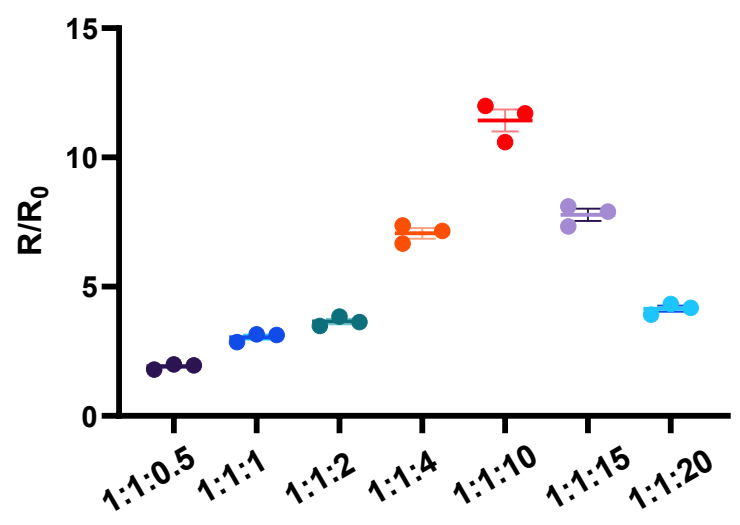

Figure S5. Measurement of signal-to-noise ratio $\left(\mathrm{R} / \mathrm{R}_{0}\right)$ in response to different ratios between $\mathbf{P 1}, \mathbf{P 2}$ and Lock-In. $[\mathbf{P 1}]=$ $[\mathbf{P 2}]=50 \mathrm{nM} ;[\mathbf{H 1}]=[\mathbf{H 2}]=200 \mathrm{nM} ;[\mathrm{HOCl}]=1 \mu \mathrm{M}$. The optimized ratio was $[\mathbf{P 1}]:[\mathbf{P 2}]:[$ Lock-In $]=1: 1: 10$. 


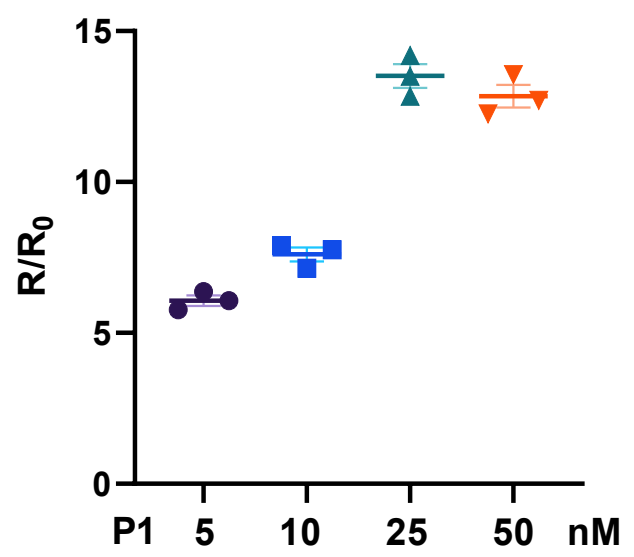

Figure S6. Measurement of R/R $\mathrm{R}_{0}$ in response to different concentration of P1, P2 and Lock-In. [P1] : [P2] : [Lock-In] = 1:1:10; $[\mathrm{HOCl}]=1 \mu \mathrm{M}$. The optimized concentrations of P1, P2 were $50 \mathrm{nM}$ and Lock-In was $500 \mathrm{nM}$.

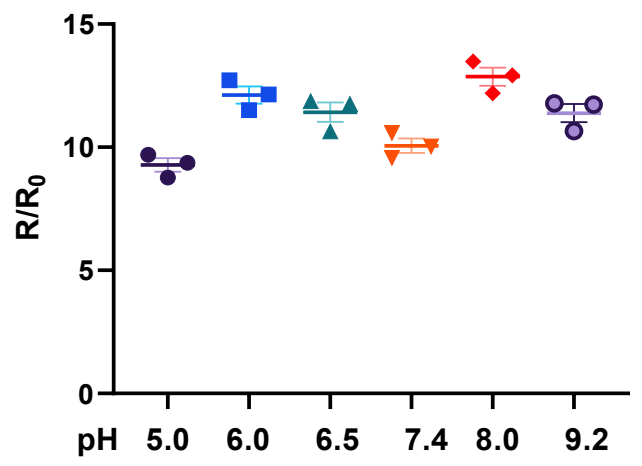

Figure S7. Measurement of R/ $\mathrm{R}_{0}$ in response to different pH. $[\mathbf{P 1}]=[\mathbf{P 2}]=50 \mathrm{nM} ;[\mathbf{H 1}]=[\mathbf{H 2}]=200 \mathrm{nM} ;[\mathbf{L o c k}-\mathbf{I n}]=500$ $\mathrm{nM} ;[\mathrm{HOCl}]=1 \mu \mathrm{M}$. The $\mathrm{pH}$ of reaction buffer had little effect on the $\mathrm{F} / \mathrm{F}_{0}$. 


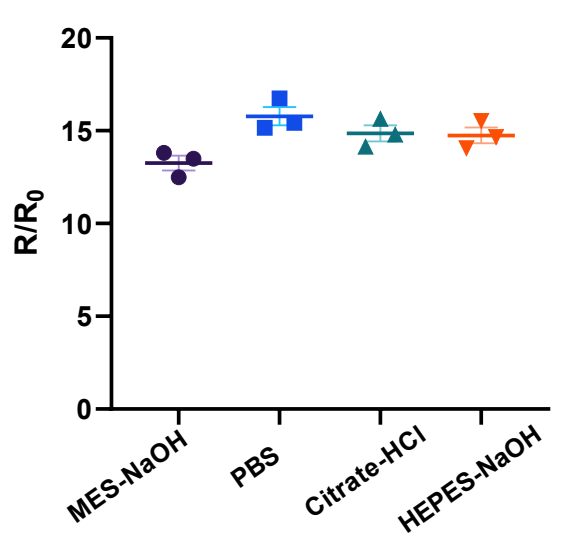

Figure S8. Measurement of $\mathrm{R} / \mathrm{R}_{0}$ in response to different types of reaction buffer. $[\mathbf{P 1}]=[\mathbf{P 2}]=50 \mathrm{nM} ;[\mathbf{H 1}]=[\mathbf{H 2}]=200$ $\mathrm{nM} ;[$ Lock-In $]=500 \mathrm{nM} ;[\mathrm{HOCl}]=1 \mu \mathrm{M}$. The types of reaction buffer had little effect on the $\mathrm{F} / \mathrm{F}_{0}$.

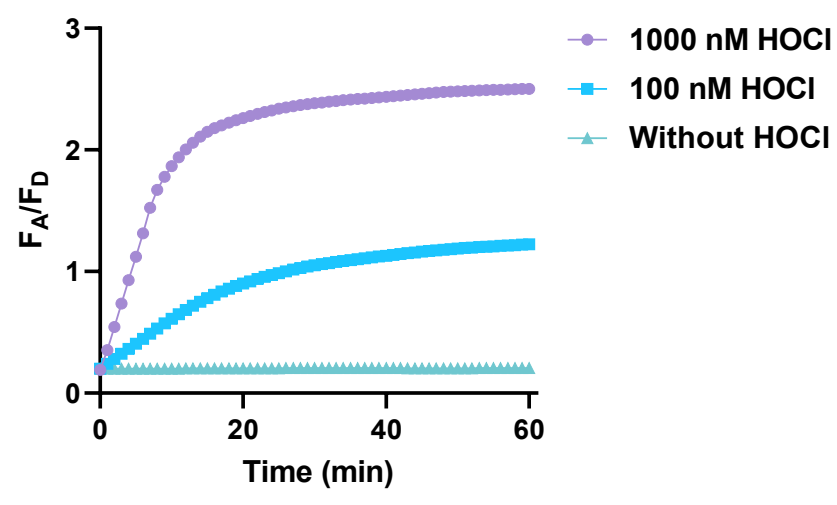

Figure S9. Measurement of the reaction kinetics in the presence of HOCl. $[\mathbf{P 1}]=[\mathbf{P 2}]=50 \mathrm{nM} ;[\mathbf{H 1}]=[\mathbf{H 2}]=200 \mathrm{nM}$; $[$ Lock-In $]=500 \mathrm{nM}$. The optimized incubation time was $30 \mathrm{~min}$. 
Table S2. Comparison of various fluorescent methods for $\mathrm{HOCl}$ detection.

\begin{tabular}{|c|c|c|c|c|}
\hline Signal modes & Materials & Linear range & Detection limit & Refs. \\
\hline Single wavelength & $\begin{array}{l}\text { Cyanine chromophore conjugated } \\
\text { upconverting nanoprobes }\end{array}$ & $3.5-17.5 \mu \mathrm{M}$ & $80 \mathrm{nM}$ & 3 \\
\hline Single wavelength & $\begin{array}{l}\text { NBD-DOP } \\
\text { fluorescent probe }\end{array}$ & $0-1 \mu \mathrm{M}$ & $9.7 \mathrm{nM}$ & 4 \\
\hline Two-photon & Imidazoline-2-thione & $0-10 \mu \mathrm{M}$ & $71 \mathrm{nM}$ & 5 \\
\hline Ratiometric & CD-RhB@ZIF-8 & $15-180 \mu \mathrm{M}$ & 6700 & 6 \\
\hline Ratiometric & CD/CCM@ZIF-8 & $0.1-50 \mu \mathrm{M}$ & $67 \mathrm{nM}$ & 7 \\
\hline Ratiometric & $\begin{array}{l}\text { Gold flowers/4-mercaptophenol } \\
\text { SERS nanoprobe }\end{array}$ & $1-63.78 \mu \mathrm{M}$ & $400 \mathrm{nM}$ & 8 \\
\hline Ratiometric & $\begin{array}{l}\text { Two semiconducting oligomers } \\
\text { and amphiphilic block copolymers } \\
\text { self-assembled organic nanoprobe }\end{array}$ & $0-20 \mu \mathrm{M}$ & $0.19 \mu \mathrm{M}$ & 9 \\
\hline Ratiometric & TDN-HCR & $2.5-200 \mathrm{nM}$ & $0.8 \mathrm{nM}$ & This work \\
\hline
\end{tabular}




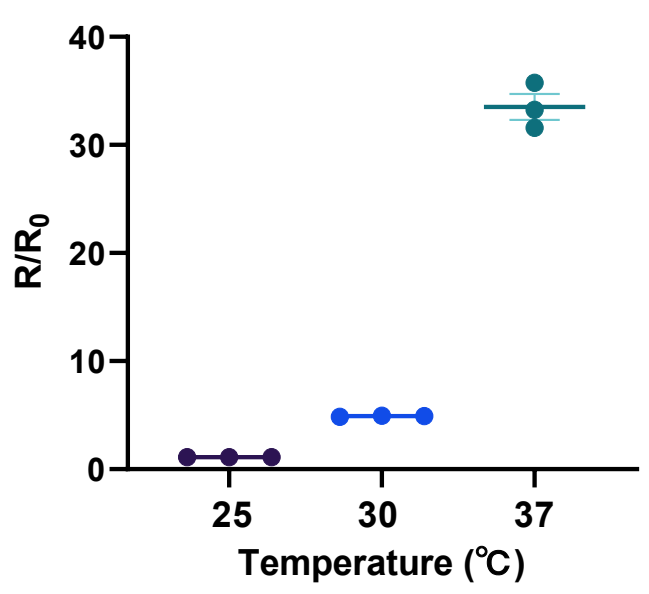

Figure S10. Measurement of R/ $\mathrm{R}_{0}$ in response to different temperature. $[\mathbf{P 1}]=[\mathbf{P 2}]=50 \mathrm{nM} ;[\mathbf{H 1}]=[\mathbf{H 2}]=200 \mathrm{nM}$; $[$ Lock-In $]$ $=200 \mathrm{nM} ;[\mathrm{MPO}]=50 \mathrm{ng} / \mathrm{mL} ;\left[\mathrm{H}_{2} \mathrm{O}_{2}\right]=\left[\mathrm{Cl}^{-}\right]=100 \mu \mathrm{M} ; \mathrm{PB} 6.0$. The optimized temperature was $37^{\circ} \mathrm{C}$.

(a)

(b)
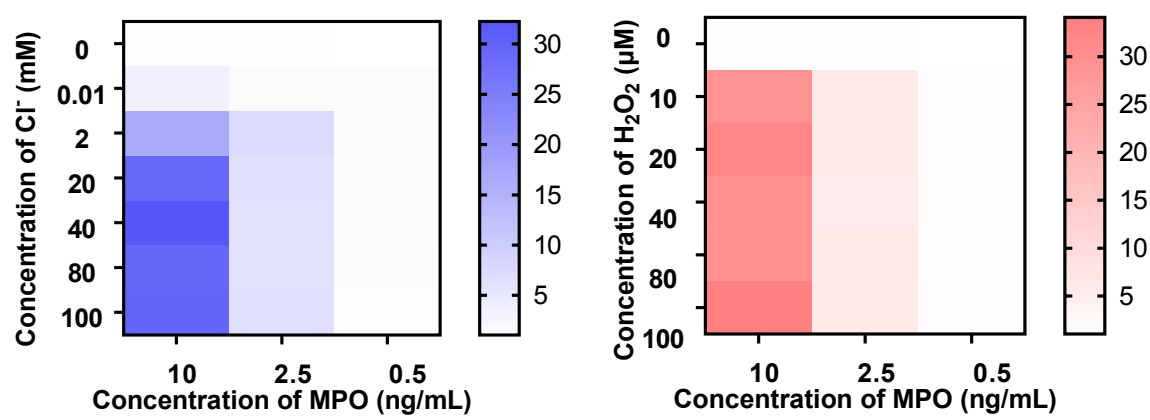

Figure S11. Measurement of $\mathrm{R} / \mathrm{R}_{0}$ in response to different concentrations of chloride ion (a) and $\mathrm{H}_{2} \mathrm{O}_{2}(\mathrm{~b})$. $[\mathbf{P} 1]=[\mathbf{P} 2]=50$ $\mathrm{nM} ;[\mathbf{H 1}]=[\mathbf{H 2}]=200 \mathrm{nM} ;[$ Lock-In $]=200 \mathrm{nM} ;[\mathrm{MPO}]=50 \mathrm{ng} / \mathrm{mL} ;$ PB 6.0. The concentrations of chloride ion (a) and $\mathrm{H}_{2} \mathrm{O}_{2}$ works over a wide range. $100 \mu \mathrm{M}$ of $\mathrm{H}_{2} \mathrm{O}_{2}$ and $\mathrm{Cl}^{-}$were used in the subsequent experiments. 


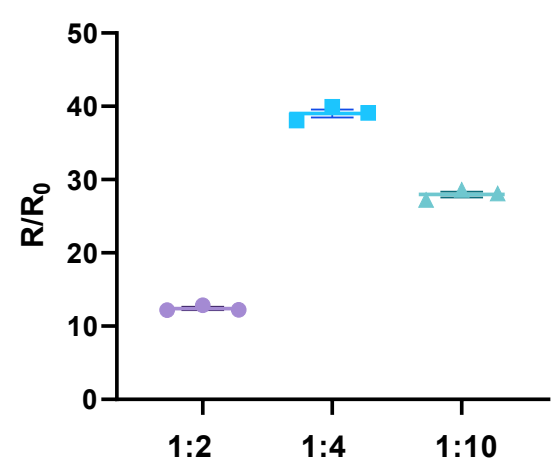

Figure S12. Measurement of R/R $\mathrm{R}_{0}$ in response to different ratios between P1 and Lock-In. $[\mathbf{P 1}]=[\mathbf{P 2}]=50 \mathrm{nM} ;[\mathbf{H 1}]=[\mathbf{H 2}]$ $=200 \mathrm{nM} ;[\mathrm{MPO}]=50 \mathrm{ng} / \mathrm{mL} ;\left[\mathrm{H}_{2} \mathrm{O}_{2}\right]=\left[\mathrm{Cl}^{-}\right]=100 \mu \mathrm{M} ; \mathrm{PB}$ 6.0. The optimized ratio was $[\mathbf{P 1}]:[$ Lock-In $]=1: 4$.

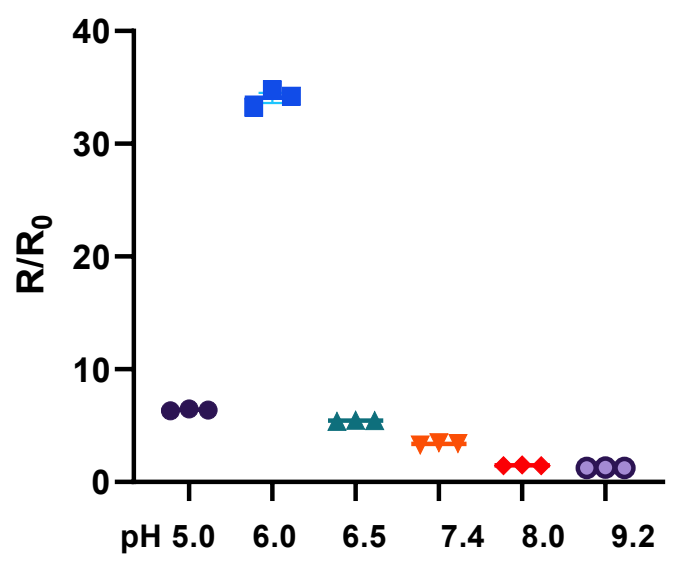

Figure S13. Measurement of R/R $\mathrm{R}_{0}$ in response to different pH. $[\mathbf{P 1}]=[\mathbf{P 2}]=50 \mathrm{nM} ;[\mathbf{H 1}]=[\mathbf{H 2}]=200 \mathrm{nM}$; [Lock-In $]=200$ $\mathrm{nM} ;[\mathrm{MPO}]=50 \mathrm{ng} / \mathrm{mL} ;\left[\mathrm{H}_{2} \mathrm{O}_{2}\right]=\left[\mathrm{Cl}^{-}\right]=100 \mu \mathrm{M}$. The optimized $\mathrm{pH}$ was 6.0 . 


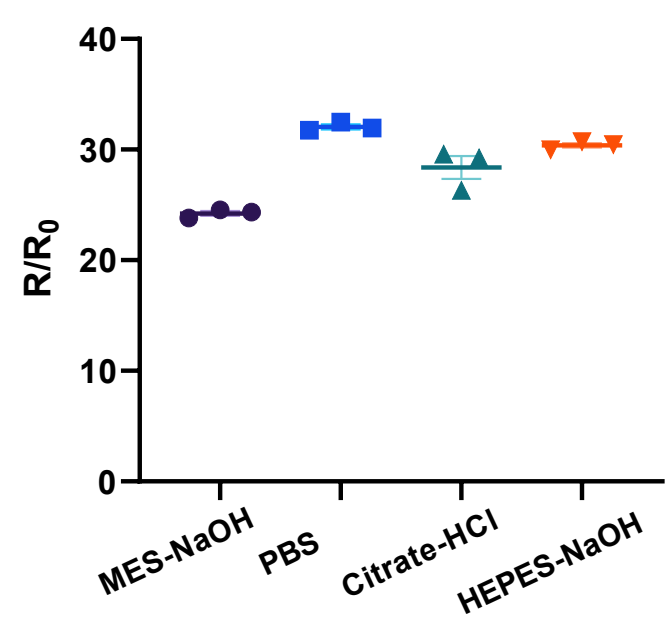

Figure S14. Measurement of $\mathrm{R} / \mathrm{R}_{0}$ in response to different types of reaction buffer. $[\mathbf{P 1}]=[\mathbf{P 2}]=50 \mathrm{nM} ;[\mathbf{H 1}]=[\mathbf{H 2}]=200$ $\mathrm{nM} ;[$ Lock-In $]=200 \mathrm{nM} ;[\mathrm{MPO}]=50 \mathrm{ng} / \mathrm{mL} ;\left[\mathrm{H}_{2} \mathrm{O}_{2}\right]=\left[\mathrm{Cl}^{-}\right]=100 \mu \mathrm{M} ; \mathrm{pH}$ 6.0. The types of reaction buffer had little effect on the $\mathrm{F} / \mathrm{F}_{0}$.

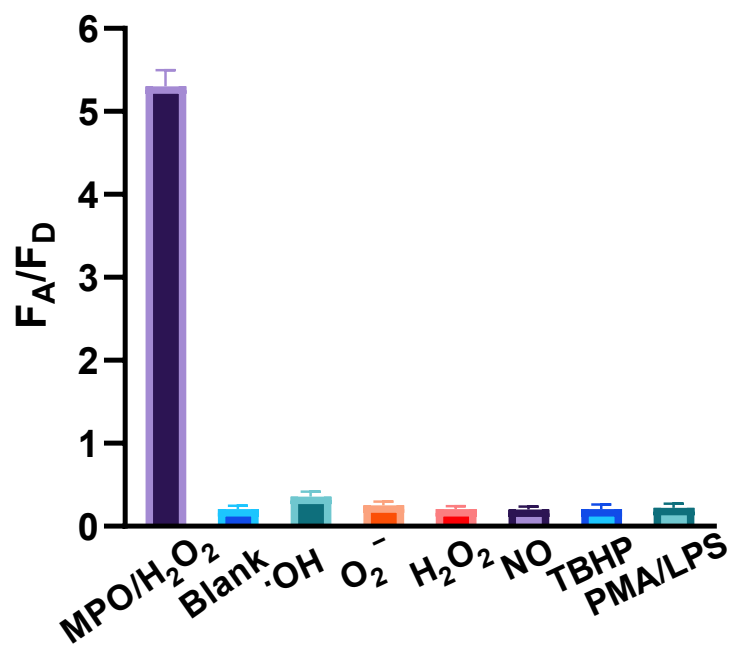

Figure S15. $\mathrm{F}_{\mathrm{A}} / \mathrm{F}_{\mathrm{D}}$ changes of the biosensor toward $\mathrm{MPO}(50 \mathrm{ng} / \mathrm{mL})$ and other oxidative species $(5 \mu \mathrm{M})$. Conditions: [P1] $=[\mathbf{P 2}]=50 \mathrm{nM},[\mathbf{H 1}]=[\mathbf{H 2}]=200 \mathrm{nM},[$ Lock-In $]=200 \mathrm{nM},\left[\mathrm{H}_{2} \mathrm{O}_{2}\right]=\left[\mathrm{Cl}^{-}\right]=100 \mu \mathrm{M}, \mathrm{PB} 6.0$, reaction at $37^{\circ} \mathrm{C}$ for $30 \mathrm{~min}$. $\lambda \mathrm{ex}=548 \mathrm{~nm}$. 
Table S3. Comparison the performance of the materials for MPO detection.

\begin{tabular}{ccccc}
\hline Materials & Methods & Linear range & Detection limit & Refs. \\
\hline $\begin{array}{c}\text { Chronoamperometric } \\
\text { Magneto Immunosensor }\end{array}$ & Immunoassay & $0.9-60 \mathrm{ng} / \mathrm{mL}$ & $0.4 \mathrm{ng} / \mathrm{mL}$ & 10 \\
N-CNT electrode & $\begin{array}{c}\text { Electrochemical } \\
\text { biosensors }\end{array}$ & $100-210 \mathrm{ng} / \mathrm{mL}$ & $70 \mathrm{ng} / \mathrm{mL}$ & 2 \\
Cy7- NphS NIR probe & Fluorescence & $0-5.5 \mathrm{ng} / \mathrm{mL}$ & $42.74 \mathrm{and} 125.94$ & 11 \\
Chemosensor 7-HCCO & Fluorescence & $0-120 \mathrm{ng} / \mathrm{mL}$ & $8 \mathrm{ng} / \mathrm{mL}$ & 12 \\
PC-UCNPs & Fluorescence & $10-200 \mathrm{ng} / \mathrm{mL}$ & $2.44 \mathrm{ng} / \mathrm{mL}$ & 13 \\
TDN-HCR & Fluorescence & $2-25 \mathrm{ng} / \mathrm{mL}$ & $0.6 \mathrm{ng} / \mathrm{mL}$ & This work \\
\hline
\end{tabular}


(a)

(b)

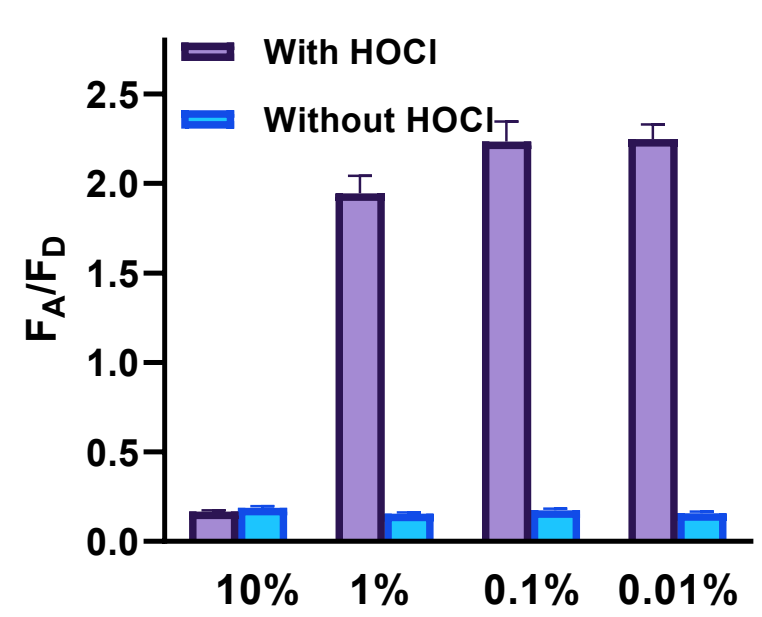

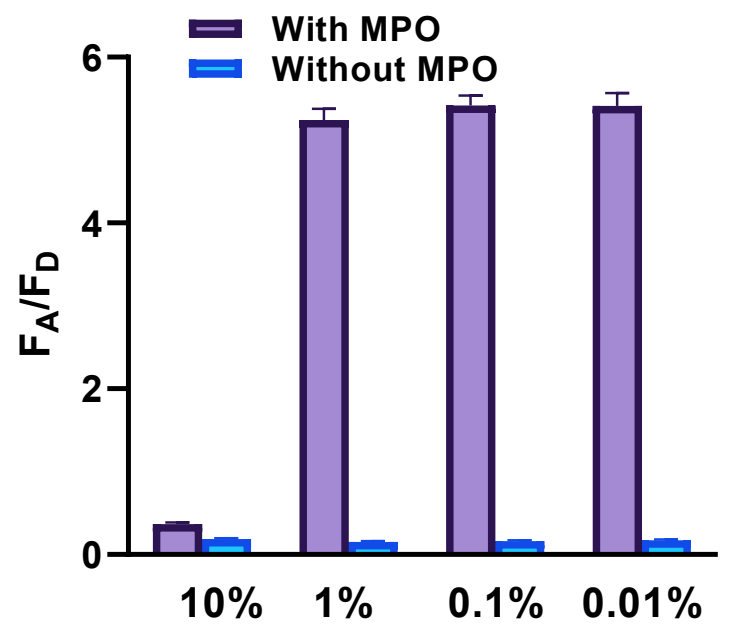

(c)

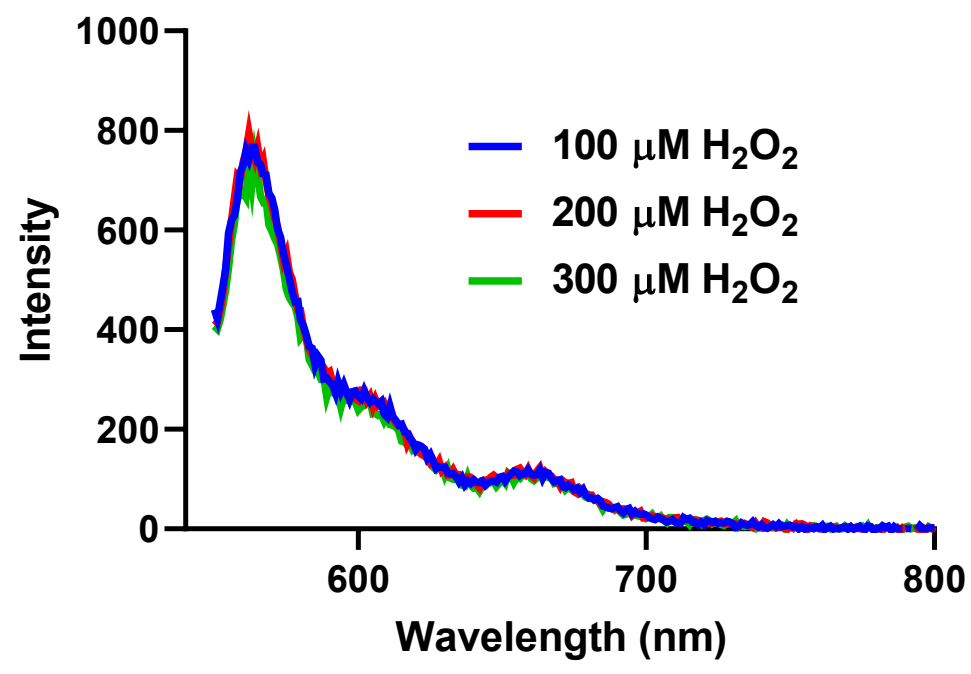

Figure S16. (a, b) The effect of plasma dilution on the biosensor for detection of $\mathrm{HOCl}$ (a) and MPO (b). (c) Fluorescent spectrum of the biosensor with MPO in response to the addition of different concentrations of $\mathrm{H}_{2} \mathrm{O}_{2}$ in 10-fold diluted plasma. Conditions: $[\mathbf{P 1}]=[\mathbf{P 2}]=50 \mathrm{nM} ;[\mathbf{H 1}]=[\mathbf{H 2}]=200 \mathrm{nM} ;[\mathrm{HOCl}]=1 \mu \mathrm{M} ;[\mathrm{MPO}]=50 \mathrm{ng} / \mathrm{mL} ;\left[\mathrm{H}_{2} \mathrm{O}_{2}\right]=\left[\mathrm{Cl}^{-}\right]=100 \mu \mathrm{M}$. 
Table S4. Recovery studies of MPO in real samples

\begin{tabular}{ccccc}
\hline Samples & Added (ng/mL) & Measured (ng/mL) & Recovery & RSD \\
\hline \multirow{3}{*}{ serum } & 2.5 & 2.451 & $98.04 \%$ & $2.56 \%$ \\
& 10 & 9.878 & $98.78 \%$ & $1.94 \%$ \\
& 20 & 21.027 & $105.14 \%$ & $2.99 \%$ \\
\hline \multirow{3}{*}{ cell lysate } & 2.5 & 2.458 & $98.32 \%$ & $2.19 \%$ \\
& 10 & 10.471 & $104.71 \%$ & $1.05 \%$ \\
& 20 & 20.545 & $102.72 \%$ & $3.31 \%$ \\
\multirow{3}{*}{ saliva } & 2.5 & 2.514 & $100.56 \%$ & $3.97 \%$ \\
& 10 & 11.051 & $110.51 \%$ & $1.19 \%$ \\
& 20 & 20.806 & $104.03 \%$ & $2.96 \%$ \\
\hline
\end{tabular}




\section{References}

1. Lee, M.-C.-i.; Velayutham, M.; Komatsu, T.; Hille, R.; Zweier, J. L., Measurement and Characterization of Superoxide Generation from Xanthine Dehydrogenase: A Redox-Regulated Pathway of Radical Generation in Ischemic Tissues. Biochemistry 2014, 53, 6615-6623.

2. Bekhit, M.; Gorski, W., Electrochemical Assays and Immunoassays of the Myeloperoxidase/SCN(-)/H2O2 System. Anal. Chem. 2019, 91, 3163-3169.

3. Peng, J.; Samanta, A.; Zeng, X.; Han, S.; Wang, L.; Su, D.; Loong, D. T.; Kang, N. Y.; Park, S. J.; All, A. H.; Jiang, W.; Yuan, L.; Liu, X.; Chang, Y. T., Real-Time In Vivo Hepatotoxicity Monitoring through Chromophore-Conjugated Photon-Upconverting Nanoprobes. Angew. Chem., Int. Ed. Engl. 2017, 56, 41654169.

4. Jiang, Y.; Zheng, G.; Cai, N.; Zhang, H.; Tan, Y.; Huang, M.; He, Y.; He, J.; Sun, H., A fast-response fluorescent probe for hypochlorous acid detection and its application in exogenous and endogenous $\mathrm{HOCl}$ imaging of living cells. Chem. Commun. (Cambridge, U. K.) 2017, 53, 12349-12352.

5. Xu, Q.; Heo, C. H.; Kim, G.; Lee, H. W.; Kim, H. M.; Yoon, J., Development of imidazoline-2-thiones based two-photon fluorescence probes for imaging hypochlorite generation in a co-culture system. Angew. Chem., Int. Ed. Engl. 2015, 54, 4890-4894.

6. Ma, Y.; Xu, G.; Wei, F.; Cen, Y.; Xu, X.; Shi, M.; Cheng, X.; Chai, Y.; Sohail, M.; Hu, Q., One-Pot Synthesis of a Magnetic, Ratiometric Fluorescent Nanoprobe by Encapsulating Fe3O4 Magnetic Nanoparticles and Dual-Emissive Rhodamine B Modified Carbon Dots in Metal-Organic Framework for Enhanced HClO Sensing. ACS Appl. Mater. Interfaces 2018, 10, 20801-20805.

7. Tan, H.; Wu, X.; Weng, Y.; Lu, Y.; Huang, Z. Z., Self-Assembled FRET Nanoprobe with Metal-Organic Framework As a Scaffold for Ratiometric Detection of Hypochlorous Acid. Anal. Chem. 2020, 92, 3447-3454. 8. Wang, W.; Zhang, L.; Li, L.; Tian, Y., A Single Nanoprobe for Ratiometric Imaging and Biosensing of Hypochlorite and Glutathione in Live Cells Using Surface-Enhanced Raman Scattering. Anal. Chem. 2016, $88,9518-9523$.

9. Yin, C.; Zhu, H.; Xie, C.; Zhang, L.; Chen, P.; Fan, Q.; Huang, W.; Pu, K., Organic Nanoprobe Cocktails for Multilocal and Multicolor Fluorescence Imaging of Reactive Oxygen Species. Adv. Funct. Mater. 2017, 27.

10. Barallat, J.; Olive-Monllau, R.; Gonzalo-Ruiz, J.; Ramirez-Satorras, R.; Munoz-Pascual, F. X.; Ortega, A. G.; Baldrich, E., Chronoamperometric magneto immunosensor for myeloperoxidase detection in human plasma based on a magnetic switch produced by 3D laser sintering. Anal. Chem. 2013, 85, 9049-9056.

11. Tian, F.; Jia, Y.; Zhang, Y.; Song, W.; Zhao, G.; Qu, Z.; Li, C.; Chen, Y.; Li, P., A HClO-specific nearinfrared fluorescent probe for determination of Myeloperoxidase activity and imaging mitochondrial $\mathrm{HClO}$ in living cells. Biosens. Bioelectron. 2016, 86, 68-74.

12. Stocker, P.; Cassien, M.; Vidal, N.; Thetiot-Laurent, S.; Pietri, S., A fluorescent homogeneous assay for myeloperoxidase measurement in biological samples. A positive correlation between myeloperoxidasegenerated HOCl level and oxidative status in STZ-diabetic rats. Talanta 2017, 170, 119-127.

13. You, Y.; Cheng, S.; Zhang, L.; Zhu, Y.; Zhang, C.; Xian, Y., Rational Modulation of the Luminescence of Upconversion Nanomaterials with Phycocyanin for the Sensing and Imaging of Myeloperoxidase during an Inflammatory Process. Anal. Chem. 2020, 92, 5091-5099. 